\title{
Measurement of Intrapreneurial Behavior In Mexican Trade Sector Companies
}

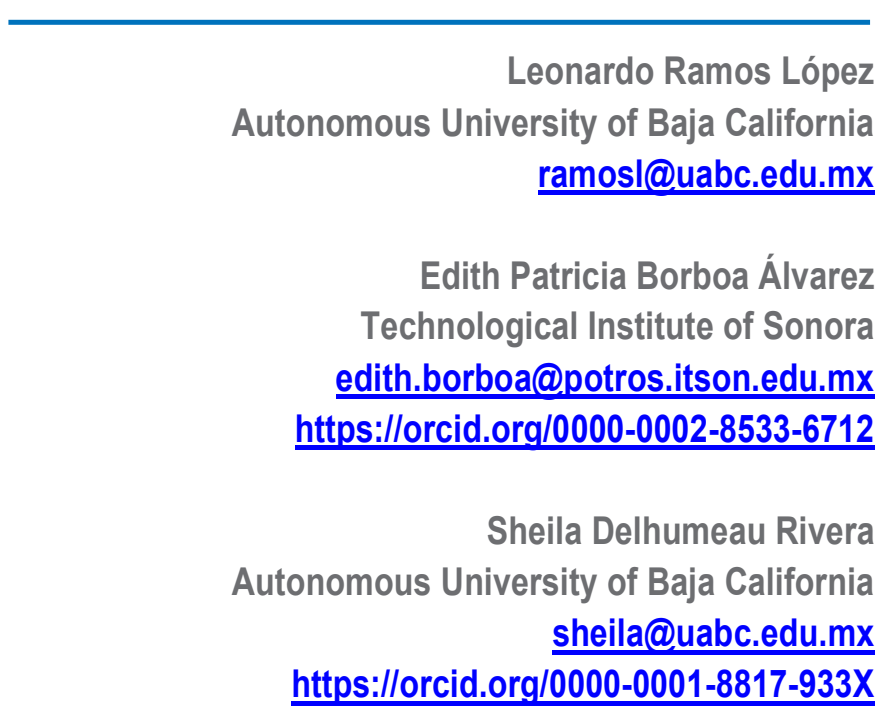

\begin{abstract}
Currently, the topic of entrepreneurship seeks to understand entrepreneurial activity and the factors behind the generation of entrepreneurial activities. However, during the last decade a new construct known as corporate entrepreneurship (CE) or intrapreneurship (IE) is considered as a concept applied in different contexts and is not yet developed thoroughly within organizations. The objective of the study is to determine the validity of a measurement instrument, whose unit of analysis is focused on employees working in companies of the trade sector in the municipality of Ensenada, Baja California, Mexico, specifically aimed at administrative employees, middle and upper management in trade companies. For the content validity, a review by seven experts was applied, followed by a pilot test with a representative sample of 30 middle management employees, then a factor analysis and the validity of Cronbach's Alpha were developed using the Statistical Package for the Social Sciences (SPSS) version 25 software, resulting in the fulfillment of the criteria of both validity and reliability in the survey applied.
\end{abstract}

KEYWORDS: Content Validity, Construct Validity, Intrapreneurship, Organizational Factors, Intrapreneurial Behavior, Trading Companies. 


\title{
Medición del Comportamiento Intraemprendedor en Empresas del Sector Comercio Mexicano
}

\author{
Leonardo Ramos López \\ Autonomous University of Baja California \\ ramosi@uabc.edu.mx \\ Edith Patricia Borboa Álvarez \\ Technological Institute of Sonora \\ edith.borboa@potros.itson.edu.mx \\ https://orcid.org/0000-0002-8533-6712 \\ Sheila Delhumeau Rivera \\ Autonomous University of Baja California \\ sheila@uabc.edu.mx \\ https://orcid.org/0000-0001-8817-933X
}

\section{Resumen}

En la actualidad, el estudio del emprendimiento busca comprender la actividad emprendedora y los factores detrás de la generación de actividades emprendedoras. Sin embargo, durante la última década se considera un nuevo constructo conocido como emprendimiento corporativo o intraemprendimiento, como un concepto aplicado en diferentes contextos y que aún no se desarrolla a fondo dentro de las organizaciones. El objetivo del estudio es determinar la validez de un instrumento de medición, cuya unidad de análisis está enfocada a los empleados que laboran en empresas del sector comercio en el municipio de Ensenada, Baja California, México, específicamente dirigido a empleados administrativos, medios y altos. Para la validez de contenido se aplicó una revisión por siete expertos, seguida de una prueba piloto con una muestra representativa de 30 funcionarios de mandos medios, luego se desarrolló un análisis factorial y la validez del Alfa de Cronbach utilizando el Paquete Estadístico para las Ciencias Sociales (SPSS ) software versión 25, dando como resultado el cumplimiento de los criterios tanto de validez como de confiabilidad en la encuesta aplicada. 


\section{Introduction}

Although it is true that Corporate Entrepreneurship (CI) is nowadays considered essential for organizations to be a starting point for their organizational growth, it is necessary to implement strategies that can help to generate internal entrepreneurial actions in these organizations, which results favorably in the influence of these business strategies to implement innovation and strategic renewal. (Göcke, Hülsebusch, and Menter, 2021).

These factors, together with the current situation in Mexico and with reference to medium-sized companies presenting constant changes and seeking to move from a traditional model to a modern one based on new opportunities aimed at generating value propositions, favoring the organization through its employees, its growth and business performance, require adapting to changes through renovations, process innovation and product or service transformations, in order to ensure their growth or permanence in the market.

Senior managers within organizations are the main promoters in charge of creating strategies for the management of an entrepreneurial attitude in human capital (Farrukh, Ying, and Mansori, 2016). Therein lies the importance for all companies to consider intrapreneurship as a key action for the success of their company in the market (Antoncic and Hisrich, 2001). It is considered as successful entrepreneurship, when this is carried out from within the organization as a key development factor (Galván-Vela and Sánchez-Limón, 2017). In addition, Kuratko (2014) states that, in the current context, intrapreneurship is relevant and should be seen as a positive factor to achieve growth and permanence in the market. Other authors agree on the importance of setting strategies in the financial performance of the organization; however, the actual implementation of this strategy remains a challenge for many organizations. (Covín and Slevin, 1990; Kaerney et al., 2013; Kreiser, Kuratko, Covin, et al., 2021).

Likewise, when organizations implement internal strategies, they develop a strong intention of entrepreneurship in order to achieve growth and international positioning, thus providing alternatives of different competences where competitiveness, proactivity, innovation and autonomy can be generated, taking advantage of new business opportunities abroad (Tonial and Rossetto, 2017; Knight and Kim, 2009). In this regard, the importance of developing this term is highlighted, since it has a positive influence on the performance and development of business organizations (Turró, Urbano and Peris-Ortiz, 2014; Zahra, 1991); also known as intrapreneurship, that development allowing growth in regional, domestic and international economic environments (Donkor, Agyekum, Kankam-Kwarteng and Aidoo, 2018; Obi, et al., 2018).

Having mentioned the above, this study shows the analysis of the validity of an instrument designed to measure intrapreneurial behavior in medium-sized companies in the trade sector located in the municipality of Ensenada, Baja California, Mexico, using a methodological design developed in phases. The first part, which begins once the instrument is developed, is submitted to validation by an odd group of expert judges, who were in charge of reviewing the content validity, by individually evaluating all the items contained in the questionnaire in its original version, to certify according to their judgment and experience that they were clear and had coherence with the research (Borboa-Alvarez and Delhumeau-Rivera, 2016). This is how the results are obtained following this validity process, reducing the items that were not relevant and keeping those that are considered to be sufficient, subsequently, we proceed to perform the measurement of the construct studied, with the reliability analysis technique of each of the variables, dimensions and factors and within the last phase, the construct validity was performed through the analysis and factors were excluded so that we could have a validated instrument. The measurement instrument passed satisfactorily the statistical tests used in the validation process, which serves as a tool to establish intrapreneurship models. 


\section{Literature Review}

Escobar-Pérez \& Cuervo-Martínez, (2008) consider reliability and validity to be essential measures for the evaluation of an instrument. Having mentioned the above and according to the author, systematic review can be defined as the instrument that has been designed to assess a possible universe of behaviors; what is sought is to measure the content validity to estimate the inferences made by the different tests, which will provide the results about each construct developed and provides a basis for the development of new ways to perform large-scale evaluation tests.

Thus, the construct that is measured with the instrument and the use of the scores obtained are fundamental aspects both for the estimation and for the conceptualization of content validity. Indeed, this type of assessment must take into account its function, that is, whether it will be used for diagnosis, measurement of skills or measurement for which there are certain validity indexes or criteria to be considered in terms of the instrument. (Ding \& Hershberger, 2002).

Pérez, Núñez, and Font (2019) mention that the proper application of methodology contributes to have a better content validity for the application, implementing different processes to obtain a final instrument ranging from the application of expert review, reliability and various analyses that help to meet the objective that is set at the beginning of work, which is where lies the importance of following these processes regardless of the situation being conducted as this will help to have better results that can serve as a basis for decision making in future lines of research. In this case, the term entrepreneur in recent years has taken great relevance and importance to perform various studies nationwide and internationally in order to understand the entrepreneurial activity from different research lines since it is considered as a generator of economic development in any country or region where it starts from an idea, the creation and implementation where it is not only about creating but also transforming or improving something already existing.

Ospina, Acosta-Prado and Castrillón, quoted by Hornsby et al (2002) and Parket (2011) within the definitions of intrapreneurship there is a consensus that expresses the following terms to talk about employees who create or promote a business idea within companies: Intrapreneurship (IE) (Susbauer 1973, Pinchot, 1985: Knight, 1987) and Corporate Entrepreneurship (CE). (Burgelman,1983 Zahra, 1991, Covin and Slevin, 1991; Sharma and Chrisman, 1999; Ireland et al., 2003; Kuratko, 2014; Parker, 2011).

This is how the various connotations of corporate entrepreneurship (CE) such as "corporate entrepreneurship", "Corporate venturing", "Intrapreneurship" (Covin and Slevin, 1991, Zahra, 1991, Martin-Rojas, García-Morales, Garrido-Moreno and García-Sánchez, 2020) conceptualize it as the process in which organizations have to generate new entrepreneurial actions starting from the initial one, looking for entrepreneurial performance, seeking business performance, better profitability and competitiveness within the environment in which they operate, considering the strategic renewal of the enterprise or the company that already exists. (Zahra,1991).

While Gunt and Ginsberg (1990) consider that intrapreneurship includes three actions, one is innovation, where the company seeks to create and develop new processes, the other is the creation of projects and the development of new business models renewing their traditional model to one that helps them to generate greater competition and growth, and finally the strategic renewal of activities that will help the organization to remain in the market and face the competition, seeking strategies that will drive growth and stability in the market.

Likewise, Blackburn et al., (2014), mention that corporate entrepreneurship (CE) is defined by the organization level increasingly by setting strategies to drive innovation and whereas it and IE is aimed at the individual level, being a bottom-up process where the initiatives are related to human resources. 
In this regard, researchers agree that both terms (Intrapreneurship or CE) have a close correlation, since they are focused on the renewal of products and services within organizations through innovation initiatives that are developed by human capital, adding trade, industrial and service strategies to be competitive in the current market. (Caseiro and Coelho, 2019).

Organizations that promote intrapreneurship actions in their employees are commonly seen as dynamic, proactive, flexible (Chebbi, Yahiaoui, Sellami, Papasolomou \& Melanthiou, 2019; Denning, 2017), since by implementing corporate entrepreneurship they generate advantage over new entrepreneurial opportunities within the organization (Davidsson, 2015; Jong, 2012), where the self-renewal of products or services, time flexibility or the creation of new products through the implementation of innovation is sought (Morris, Kuratko \& Covin, 2011) resulting in a higher probability of success in companies to develop internal entrepreneurship. (Urban \& Wood, 2017). Felgueira and Rodriguez (2020) agree with the authors Miller and Friesen (1982) when they say that companies implementing constant innovation, taking risks, developing competitive strategies and generating new products in the market have better entrepreneurship indexes, looking for new business opportunities, that is, the orientation of these companies are focused on innovation, proactivity and autonomy to achieve this approach of organizations that generate these internal entrepreneurship processes.

Likewise, Kraus, Breier, Jones and Hughes (2019) mention that organizations are under pressure to reach the digital era where employees have great possibilities of discovery in order to generate individual intrapreneurship bases, as they are always looking for new opportunities working in exploratory activities and this usually starts in senior management within an organization due to the level of preparation and training that companies provide them.

Pinchot (1985) argues that intrapreneurship allows the development of markets within an organization and relatively independent units designed to create, internally, test and expand markets and/or innovative services, technologies or methods. "Collaboration between an entrepreneur and his/her company, allows him/her to develop his/her own projects, independently of his/her job, and from there, sometimes, a trade project emerges". (Vega 2016).

On the other hand, there is the entrepreneurial behavior that can develop within medium and large established organizations, which includes terms such as entrepreneurial organizations, intrapreneurship and venture capital. (Morris, Kuratko \& Covin, 2011).

Consequently, the internal organizational factors, according to the intrapreneurship literature, are identified as contributors to the generation of this entrepreneurial action. Antoncic and Hisrich, 2001; Covin and Slevin, 1991; Guth and Ginsber, 1990; Ireland, 2009, Kearney, 2013; Kuratko, 2014; Galván and Sánchez, 2017, 2018, consider several factors ranging from the area of leadership, organizational, company principles, policies and regulations (Villiersscheepers,2012).

In other words, internal organizational factors are defined as being composed of elements that the organization itself has, as well as internal variables that are related to philosophy and management that apply: values, beliefs, strategies, according to Covin and Slevin (1991). The organizational resources such as: monetary, equipment, skills, organizational culture: values, beliefs, attitudes towards the individual and finally the organizational structure that establishes communication, relationship and centralization or decentralization.

Indeed, Abbas and Wu (2019) in their study: the moderating role of intrapreneurial personality and the relationship with leader characteristics and innovative behavior, mention that the characteristics of humble leaders contribute positively to intrapreneurial behavior in employees at the individual level and among them offer recommendations to the organization and to managers about how to maximize innovation. 
García, J. C., Sánchez, B., Flórez, J., Helena, S., and Gabriel, V. (2017) mention that the individual personality and the different behaviors are found in essential entrepreneurs. Therefore, it is of utmost importance to carry out different studies that contribute to identify the most appropriate profile to generate these behaviors within organizations, values, beliefs and motives that help to better identify the characteristics of the entrepreneur.

External factors or also known as environmental factors or elements of the environment, are considered to be the starting points in corporate entrepreneurship models (Covin and Slevin 1991, Antoncic and Hisrich 2001; from Villiers-scheepers 2012, Ireland 2009; Kearnet 2013). Elements define it as those external factors that impact on the organization's functioning. Therefore, these factors inhibit or facilitate intrapreneurship, depending on the place where the activities are performed, as mentioned by Antoncic and Hisrich (2000) taken up by Trujillo and Guzmán (2008) in their study: review of the intrapreneurship construct, where the external environment is the scenario where factors and barriers arise conditioning the intrapreneurship process. Finally, the external factors of organizations such as regulations, government policies, collaborative work with communities that affect corporate entrepreneurship and its relationship with the innovation process outcomes to achieve competitive advantage. (Bedoya, Toro and Arango, 2017).

\section{Problem and Hipothesis}

Kearney, Hisrich and Antoncic (2013) define intrapreneurship as the action that takes place within organizations where employees find new opportunities to engage in acts of entrepreneurship involving risks through renewal, innovation and proactivity.

That is, for organizations that continue with a traditional model of operations causes stagnation in the market due to lack of vision and business growth by not meeting market needs, and on the contrary through the use of resources and employees contributes to generate intrapreneurial behavior action, with new products, improving services, renewing strategies that contribute to differentiation in the market (Antoncic and Hisrich 2001).

Small and medium-sized enterprises (SMEs) are important actors in the study of intrapreneurial behavior since they are currently affected by different changes in the economic, political or social context, therefore the importance of their adaptation to the environment is fundamental for their permanence, since most of them seek to implement new processes, innovation, transformation of new ideas within the company through the support and development of creativity, seeking to generate competitive ideas in the market.

SMEs in Mexico are taken as a relevant factor since they are considered as generators of employment and promoters of economic development through entrepreneurship of a business idea where they cover areas unattended by large businesses and services. In addition to this, they boost the economy of the region. (Velázquez et al, 2016).

Rangel, Navarro and Márquez, (2020) emphasize the importance to implement changes within the organizations in order to promote entrepreneurship as a key factor that promotes internal change and paves the way for owners and collaborators to commit to the possibility that their employees are able to generate an internal change that will allow growth.

Therefore, this gap creates the opportunity to generate new lines of research on key elements for modern management practices to stimulate the role of entrepreneurs within organizations and create organizational value. Emphasis is placed on strategy, structure and culture as the pillars that companies must have to encourage intrapreneurship, followed by individual factors, competencies, behaviors and the role of the corporate entrepreneur (Bedoya, Toro and Arango, 2017), from which the following research questions arise: 
Which are the main internal organizational factors that meet the criteria of validity and reliability in intrapreneurial behavior among medium-sized companies within the trade sector in the municipality of Ensenada Baja California, Mexico?

Which are the main external factors that meet the criteria of validity and reliability in the development of intrapreneurial behavior among medium-sized companies within the trade sector in the municipality of Ensenada, Baja California, Mexico?

Which individual characteristics meet the criteria of validity and reliability in the development of intrapreneurial behavior among medium-sized companies in the trade sector located in the municipality of Ensenada, Baja California, Mexico?

\section{Methodology}

The methodology used for this research is based on a mixed approach with a process of content validity conducted by experts, and the application of various statistical tests such as reliability analysis (Cronbach's alpha), factor analysis using the Kaiser-Meyer-Olkin (KMO) measure and Bartlett's test of sphericity, for each of the variables and dimensions addressed in the intrapreneurial behavior. The objective of the study is to determine the validity of a measurement instrument, whose unit of analysis is focused on employees working in the trade sector companies in the municipality of Ensenada, Baja California, Mexico, specifically aimed at administrative employees, middle and upper management in trade companies, in the grocery, hardware, spare parts and stationery sectors. According to Borboa-Alvarez and Delhumeau-Rivera (2016), to start the content validity process it is required to clearly identify the situation to be measured and then select some of its elements to be tested, which for this case, first of all, the design of the instrument is carried out as phase one, where through the different models and scales, the questionnaire to measure the corporate entrepreneurship in the trade sector under study is defined, then, in the second phase, the validation of content by judges, where seven experts were selected according to their professional experience and knowledge on the subject and carried out the validation process of each item that made up the original instrument. (Escobar-Pérez and Cuervo-Martínez, 2008; Borboa-Álvarez et al., 2020).

Gallardo, Sanchez and Corchuelo (2013) also mention that content validity helps to determine the degree of relationship among the contracts and the causal relationships that arise during the instrument design, which is where the importance of a systematic review lies in order to obtain better results at the time of applying the questionnaire, so as to have a better scientific accuracy. In the next phase, the pilot test continued with field work according to the sample determined, followed by the restructuring suggested by the judges, the pertinent changes were made for its application, where a representation of 30 respondents in charge of areas, managers and administrative staff were selected and it was ensured that they clearly understood the instrument applied. Once the data had been collected, we continued with the last stage, where the reliability analysis and factor analysis were carried out in order to measure the degree of internal correlation between the items. In addition, the Exploratory Factor Analysis (EFA) was performed to determine the factors measured by the instrument through the statistical program "Statistical Package for the Social Sciences" (SPSS), through this statistical program the factors evaluating the instrument are identified and the validity of each construct can be checked. At this stage, items that did not contribute to the instrument were eliminated through the results of the KMO and Barlett tests, as well as the integration of each of the factors with their corresponding dimensions. (Tobón, 2020).

The first section of the instrument contained the sociodemographic variables, with general questions on gender, company sector, years in the market, employee's age, monthly work salary, area of the organizational structure (position) and schooling, all of which allow us to identify the main characteristics of the research subjects. This is followed by the sections with the scales proposed to measure the research, which allowed the construction of the complete instrument, in 
order to check the behavior of the variables mentioned in the models of the instruments used for the measurement of this study, such as: Corporate Entrepreneurship Scale Zahra (1991), Antoncic and Hisrich (2001), Scale based on the Corporate Entrepreneurship Assessment Instrument (CEAI) instrument, validated by Kuratko et al. (1990), Donald F. Kuratko and Jeffrey S. Hornsby (2014), Moriano et al., 2009 Razavi and Ab Aziz 2017; Galván, Sánchez and Sánchez, 2017; Individual Characteristics by John et al., 1999; Jeroen et al 2008The scale used in this section is a Likert-type, five-point scale considering the following responses and values $1=$ Strongly disagree, $2=$ Disagree, $3=$ Moderately agree, $4=$ Agree, $5=$ Strongly agree. The procedure for content validity began with the adjustment of the items to the context under investigation, as well as the translation from English to Spanish, adapting them appropriately so that respondents would find them clear and the original meaning would not be lost. Table 1 shows how the original version of the instrument is made up, where it can be seen that it began with 151 items.

Table 1: Initial instrument variable model

\begin{tabular}{|c|c|c|c|}
\hline Variable & Dimension & Items & \# Items \\
\hline \multirow[t]{2}{*}{ External Organizational Factors } & Munificence & $1-20$ & 20 \\
\hline & Hostility & $21-26$ & 6 \\
\hline \multirow[t]{6}{*}{ Internal organizational factors } & Management support & $27-38$ & 12 \\
\hline & Autonomy & $39-47$ & 9 \\
\hline & Communication & $48-52$ & 5 \\
\hline & Organizational Boundaries & $53-62$ & 10 \\
\hline & Rewards & $63-69$ & 7 \\
\hline & Time availability & $70-75$ & 6 \\
\hline \multirow[t]{8}{*}{ Individual characteristics } & Openness & $76-84$ & 9 \\
\hline & Pleasantness & $85-93$ & 9 \\
\hline & Awareness & $94-101$ & 8 \\
\hline & Extroverted & $102-108$ & 7 \\
\hline & Neuroticism & $10-116$ & 8 \\
\hline & Perception of own abilities & $117-124$ & 8 \\
\hline & Past experience and knowledge & $125-127$ & 3 \\
\hline & Relationship with the organization & $128-133$ & 6 \\
\hline \multirow[t]{4}{*}{ Intrapreneurship } & Innovation & 134-139 & 6 \\
\hline & Proactivity & $140-143$ & 4 \\
\hline & Recognition of opportunities & $144-146$ & 3 \\
\hline & Networking & $147-151$ & 5 \\
\hline
\end{tabular}

Note: Table representing the variables, dimensions and items that make up the measurement instrument in its initial version before the assessment. (Source: own elaboration). 
In the evaluation of experts section, different researchers were invited according to their profile, experience and knowledge of the topic being addressed. Likewise, the evaluation of the content of the instrument was requested, where the experts who have a significant and relevant trajectory in the research allowed them to issue a judgment and assessment on the topic already mentioned. (Escobar-Pérez \& Cuervo-Martínez, 2008).

The process of expert judgment to each of the experts was carried out by sending the instrument in Excel format with columns so that they could add their comments and evaluate according to the criteria established by the author, where they had to evaluate the 151 items that make up the original instrument. Once the evaluation was made by each one of them, the judges gave their opinion regarding the coherence, relevance and quality indicators as shown in Table 2, the model used, together with the values from one, which means "does not meet the criteria", to four, which indicates "high level of compliance" were determined to evaluate the content of each item.

Table 2: Assessment model.

\begin{tabular}{|c|c|c|}
\hline Category & Qualification & Indicator \\
\hline Sufficiency & 1. Does not meet the criterion & The items are not sufficient to measure the dimension. \\
\hline \multirow{3}{*}{$\begin{array}{l}\text { The items belonging to the } \\
\text { same dimension are } \\
\text { sufficient to obtain the } \\
\text { measurement of this one. }\end{array}$} & 2. Low Level & $\begin{array}{l}\text { The items measure some dimension aspect, but do not } \\
\text { correspond to the total dimension. }\end{array}$ \\
\hline & 3. Moderate level & $\begin{array}{l}\text { Some items should be increased in order to evaluate the } \\
\text { dimension completely. }\end{array}$ \\
\hline & 4. High level & The items are sufficient. \\
\hline Clarity & 1. Does not meet the criterion & The item is not clear. \\
\hline \multirow{3}{*}{$\begin{array}{l}\text { The item is easily } \\
\text { understood, i.e., its syntax } \\
\text { and semantics are } \\
\text { adequate. }\end{array}$} & 2. Low Level & $\begin{array}{l}\text { The item requires a lot of modifications or a very large } \\
\text { modification in the use of words according to their meaning } \\
\text { or word order. }\end{array}$ \\
\hline & 3. Moderate level & Some of the item's terms require a very specific modification. \\
\hline & 4. High level & Some of the item's terms require a very specific modification. \\
\hline Coherence & 1. Does not meet the criterion & The item has no logical relationship to the dimension. \\
\hline \multirow{3}{*}{$\begin{array}{l}\text { The item has a logical } \\
\text { relationship with the } \\
\text { dimension or indicator it is } \\
\text { measuring. }\end{array}$} & 2. Low Level & The item has a tangential relationship to the dimension. \\
\hline & 3. Moderate level & $\begin{array}{l}\text { The item has a moderate relationship with the dimension it is } \\
\text { measuring. }\end{array}$ \\
\hline & 4. High level & $\begin{array}{l}\text { The item is completely related to the dimension it is } \\
\text { measuring. }\end{array}$ \\
\hline Relevance & 1. Does not meet the criterion & $\begin{array}{l}\text { The item can be eliminated without affecting the } \\
\text { measurement of the dimension. }\end{array}$ \\
\hline \multirow{3}{*}{$\begin{array}{l}\text { The item is essential and } \\
\text { important, i.e., it must be } \\
\text { included. }\end{array}$} & 2. Low Level & $\begin{array}{l}\text { The item has some relevance, but another item may be } \\
\text { including what this item measures. }\end{array}$ \\
\hline & 3. Moderate level & The item is relatively important. \\
\hline & 4. High level & The item is highly relevant and should be included. \\
\hline
\end{tabular}

Source: Escobar-Pérez and Cuervo-Martínez (2008). 


\section{Results}

Once the judges had made their observations on the instrument, these were analyzed and decisions were made regarding the suggestions of each one to restructure the instrument, where 34 items were eliminated from the 152, leaving 117 in the end, which were considered in the pilot test of the population under study, as shown in the model of Table 3 . To carry it out, the instrument was loaded in the Google Forms platform so as to apply these items online, then the different companies in the trade sector were contacted through electronic media and telephone calls, so that they could answer the instrument online and we had responses from 30 surveyed organizations.

Table 3: Variables model of the final instrument.

\begin{tabular}{|c|c|c|c|}
\hline Variable & Dimension & Items & \# Items \\
\hline \multirow[t]{2}{*}{ External Organizational Factors } & Munificence & $1-15$ & 15 \\
\hline & Hostility & $16-20$ & 5 \\
\hline \multirow[t]{6}{*}{ Internal Organizational Factors } & Management support & $21-28$ & 8 \\
\hline & Autonomy & $29-33$ & 5 \\
\hline & Communication & $34-40$ & 7 \\
\hline & Organizational Boundaries & $41-47$ & 7 \\
\hline & Rewards & $48-52$ & 5 \\
\hline & Time availability & $53-56$ & 4 \\
\hline \multirow[t]{8}{*}{ Individual characteristics } & Openness & $57-59$ & 3 \\
\hline & Pleasantness & $60-63$ & 4 \\
\hline & Awareness & 64-67 & 4 \\
\hline & Extroverted & $68-70$ & 3 \\
\hline & Neuroticism & $71-74$ & 4 \\
\hline & Perception of own abilities & $75-79$ & 5 \\
\hline & Past experience and knowledge & $80-82$ & 3 \\
\hline & Relationship with the organization & $83-87$ & 5 \\
\hline \multirow[t]{4}{*}{ Intrapreneurship } & Innovation & $88-92$ & 5 \\
\hline & Proactivity & 93-95 & 3 \\
\hline & Recognition of opportunities & $96-98$ & 3 \\
\hline & Networking & $99-102$ & 4 \\
\hline
\end{tabular}

Note: Table representing the variables, dimensions and items that make up the measurement instrument in its final version after the evaluation (Source: own elaboration).

The purpose of this pilot test was to verify how well each of the instrument's constructs is, performing a reliability analysis, determining its Cronbach's alpha and verifying if it meets the acceptance criteria, which, if not, could have an adjustment in each of the dimension items considered. In order to check the reliability and internal consistency of each scale of this 
instrument, to determine a satisfactory value of Cronbach's Alpha above 0.6 for the social sciences (Fiel, 2009), Table 4 shows the reliability results for each of the dimensions.

Internal consistency reliability assesses the ability of the indicator to measure its latent construct (Memon et al., 2017). The tool used to assess this is composite reliability and Cronbach's Alpha. Composite reliability score $0.6-0.7$ is considered to have good reliability (Sarstedt et al., 2017), and the expected Cronbach's Alpha value is above 0.7. (Ghozali and Latan, 2015).

Accordingly, in this table, once the expert evaluation and pilot test have been passed, it can be observed that there are certain dimensions that pass the criteria to be considered as good reliability, in this sense, we proceed to perform the exploratory factor analysis to continue with the validation and improvement of each of the constructs proposed in this research.

Table 4: Reliability Analysis

\begin{tabular}{|c|c|}
\hline Variable & Cronbach's Alpha \\
\hline \multicolumn{2}{|l|}{ External Organizational Factors } \\
\hline - $\quad$ Munificence & .936 \\
\hline - $\quad$ Hostility & .905 \\
\hline \multicolumn{2}{|l|}{ Internal Organizational Factors } \\
\hline - $\quad$ Management support & .958 \\
\hline - $\quad$ Autonomy & .875 \\
\hline - $\quad$ Communication & .949 \\
\hline - $\quad$ Organizational Boundaries & .946 \\
\hline - $\quad$ Rewards & .968 \\
\hline - $\quad$ Time availability & .802 \\
\hline \multicolumn{2}{|l|}{ Individual Characteristics } \\
\hline - $\quad$ Openness & .942 \\
\hline - $\quad$ Pleasantness & .919 \\
\hline - $\quad$ Awareness & .961 \\
\hline - $\quad$ Extroverted & .950 \\
\hline - $\quad$ Neuroticism & .916 \\
\hline - $\quad$ Perception of own abilities & .980 \\
\hline - $\quad$ Past experience and knowledge & .930 \\
\hline - $\quad$ Relationship with the organization & .953 \\
\hline \multicolumn{2}{|c|}{ Intrapreneurship } \\
\hline - $\quad$ Innovation & .958 \\
\hline - $\quad$ Proactivity & .960 \\
\hline - $\quad$ Recognition of opportunities & .915 \\
\hline - $\quad$ Networking & .937 \\
\hline
\end{tabular}


After having presented different reliability analyses of each dimension, it can be concluded that each of the scales represents a reliable internal consistency, since all the variables present a Cronbach's alpha higher than 0.6 , which indicates compliance with the approval indicators.

As for the factor analysis in Table 5, for each of the variables that make up the intrapreneurial behavior instrument, the final result was the elimination of 15 items that did not contribute and did not comply with their corresponding factor. This resulted in a final instrument, validated with the different statistical tests, containing a total of 102 items.

The main objective of this exploratory factor analysis was to identify the latent factors in the set of constructs developed that had the integration.

First, we began with the data adjustment and its correlation matrix, determination of the number of factors as well as the rotation of them, thus eliminating items that did not comply with the same factor.

It can be identified from the sphericity test and the KMO that the correlation obtained in its significance is a value of 0 , which shows us the high degree of intercorrelations of the variables. This result is also confirmed by the significance of Barlett's sphericity test, which is 0.00 , while the KMO shows a value higher than 0.80 , which indicates that the sample is appropriate to perform this factor.

Table 5: Exploratory factor analysis

\begin{tabular}{|c|c|c|c|c|c|c|c|}
\hline \multirow[t]{3}{*}{ Independent Variable } & \multirow[t]{3}{*}{ Dimensions } & \multirow{3}{*}{$\begin{array}{c}\text { Original } \\
\text { Items }\end{array}$} & \multirow{3}{*}{$\begin{array}{l}\text { Eliminated } \\
\text { Items }\end{array}$} & \multicolumn{4}{|c|}{ KMO and Bartlett's test } \\
\hline & & & & \multirow[t]{2}{*}{ Kaiser-Mayer } & \multirow[t]{2}{*}{ Sphericity Test } & \multicolumn{2}{|c|}{ Bartlett } \\
\hline & & & & & & gl & Sig \\
\hline \multirow{2}{*}{$\begin{array}{c}\text { External Organizational } \\
\text { Factors }\end{array}$} & Munificence & \multirow[t]{2}{*}{20} & \multirow[t]{2}{*}{0} & \multirow[t]{2}{*}{0,855} & \multirow[t]{2}{*}{451,061} & \multirow[t]{2}{*}{91} & \multirow[t]{2}{*}{0} \\
\hline & Hostility & & & & & & \\
\hline \multirow{6}{*}{$\begin{array}{c}\text { Internal Organizational } \\
\text { Factors }\end{array}$} & $\begin{array}{l}\text { Management } \\
\text { support }\end{array}$ & \multirow{6}{*}{43} & \multirow{6}{*}{7} & & & & \\
\hline & Autonomy & & & & & & \\
\hline & Communication & & & & & & \\
\hline & $\begin{array}{l}\text { Organizational } \\
\text { Boundaries }\end{array}$ & & & & & & \\
\hline & Rewards & & & & & & \\
\hline & Time availability & & & & & & \\
\hline \multirow{8}{*}{ Individual Characteristics } & Openness & \multirow[t]{8}{*}{37} & \multirow[t]{8}{*}{6} & & & & \\
\hline & Pleasantness & & & & & & \\
\hline & Awareness & & & & & & \\
\hline & Extroverted & & & & & & \\
\hline & Neuroticism & & & & & & \\
\hline & $\begin{array}{l}\text { Perception of own } \\
\text { abilities }\end{array}$ & & & & & & \\
\hline & $\begin{array}{l}\text { Past experience } \\
\text { and knowledge }\end{array}$ & & & & & & \\
\hline & $\begin{array}{l}\text { Relationship with } \\
\text { the organization }\end{array}$ & & & & & & \\
\hline \multirow{4}{*}{ Intrapreneurial Behavior } & Innovation & \multirow{4}{*}{18} & \multirow{4}{*}{3} & \multirow{4}{*}{0,764} & \multirow{4}{*}{595,389} & \multirow{4}{*}{105} & \multirow{4}{*}{0} \\
\hline & Proactivity & & & & & & \\
\hline & $\begin{array}{l}\text { Recognition of } \\
\text { opportunities }\end{array}$ & & & & & & \\
\hline & Networking & & & & & & \\
\hline
\end{tabular}


On the other hand, Table 6 shows the results of reliability analysis after the elimination of items according to the factor analysis, where all results show positive significance according to the acceptable score, all above .8 .

Thus, the Cronbach's Alpha of each dimension is positively according to the above mentioned. The composite reliability score $0.6-0.7$ is considered to have good reliability (Sarstedt et al., 2017), and the expected Cronbach's Alpha value is above 0.7 (Ghozali and Latan, 2015). Most of these dimensions stay in the expected range of values which can be said to be ready for application in the intended context.

Table 6: Reliability analysis

\begin{tabular}{|c|c|}
\hline Variable & Cronbach's Alpha \\
\hline \multicolumn{2}{|l|}{ External Organizational Factors } \\
\hline - $\quad$ Munificence & .936 \\
\hline - $\quad$ Hostility & .905 \\
\hline \multicolumn{2}{|l|}{ Internal Organizational Factors } \\
\hline - $\quad$ Management support & .950 \\
\hline - $\quad$ Autonomy & .875 \\
\hline - $\quad$ Communication & .949 \\
\hline - $\quad$ Organizational Boundaries & .938 \\
\hline - $\quad$ Rewards & .960 \\
\hline - $\quad$ Time availability & .828 \\
\hline \multicolumn{2}{|l|}{ Individual Characteristics } \\
\hline - Openness & .920 \\
\hline - $\quad$ Pleasantness & .879 \\
\hline - $\quad$ Awareness & .942 \\
\hline - $\quad$ Extroverted & .926 \\
\hline - $\quad$ Neuroticism & .916 \\
\hline - $\quad$ Perception of own abilities & .975 \\
\hline - $\quad$ Past experience and knowledge & .930 \\
\hline - $\quad$ Relationship with the organization & .934 \\
\hline \multicolumn{2}{|l|}{ Intrapreneurship } \\
\hline - Innovation & .943 \\
\hline - $\quad$ Proactivity & .943 \\
\hline - $\quad$ Recognition of opportunities & .915 \\
\hline - $\quad$ Networking & .905 \\
\hline
\end{tabular}

\section{Conclusions}

Instrument validity and construction shows the information needed for the correct use of the instrument, fulfilling the main phases in the process of content, construct and reliability validity: evaluation by expert judges, reliability analysis and exploratory factor analysis.

In this sense, it can be concluded that, according to all these tests carried out on the instrument presented, 34 items were eliminated as they did not contribute to the instrument according to the 
experts' agreement, having a total of 151 questions at the beginning and after the evaluation of the judges, it was reduced to 117 items for the application of the pilot test.

Once the pilot test was applied to 30 surveys of the trade sector of middle, managerial and administrative ranks, reliability tests and factorial analysis were carried out, and 15 items had to be eliminated from these analyses because their factor load was not related to their dimension since the surveys did not perceive it that way; likewise, the items with Cronbach's Alpha were also eliminated because they did not have the result that was desirable for their acceptance.

The instrument was composed of 102 items ready to be applied to the representative sample in order to achieve the research objective, since it will show the credibility of the study through different statistical tests. Likewise, the questionnaire used has the advantage of adequacy, since it arises from validated and replicated models, such as the Scale based on the Corporate Entrepreneurship Assessment Instrument (CEAI) validated by Kuratko et al. (1990), Donald F. Kuratko and Jeffrey S. Hornsby (2014), Moriano et al., 2009 Razavi and Ab Aziz 2017; Galván, Sánchez and Sánchez, 2017; Individual Characteristics John et al., 1999. In summary, the measurement instrument satisfactorily passed the statistical tests used within the validation process, which serves as a guide for future studies related to the research line addressed. Each of the objectives were satisfactorily fulfilled, both the intrapreneurial behavior, individual characteristics, external and internal organizational factors were positively adapted, achieving a validated and structured instrument for its application in the medium-sized companies from the trade sector in the municipality of Ensenada, Baja California, Mexico.

Finally, it can be mentioned as a limitation, to continue with the analysis of the instrument in subsequent studies and to complement the construct validity through a confirmatory factor analysis in the questionnaire designed to be applied later to the selected sample.

\section{References}

Abbas, W., y Wu, w (2019), The moderating role of intrapreneurial personality in relation between leader humility and innovative behavior, Human System Management, 38 (4),329-337

Antoncic, B., y Hisrich, R. D. (2001). Intrapreneurship: Construct refinement and cross-cultural validation. Journal of Business Venturing, 16(5), 495-527. https://doi. org/10.1016/S0883-9026(99)00054-3.

Bedoya, M. A., Toro, I. D., y Arango, B. (2017). Emprendimiento corporativo e innovación: Una revisión y futuras líneas de investigación. Revista Espacios, 38(17).

Blackburn, R., Delmar, F., Fayolle, A. y Welter, F. (2014). Entrepreneurship, People and Organizations: Frontiers in European Entrepreneurship Research. Cheltenham, UK: Edward Elgar.

Borboa-Álvarez, E. P., \& Delhumeau-Rivera, S. (2016). Validez de contenido de un instrumento para medir la responsabilidad social de las empresas bancarias. RECAI Revista de estudios en contaduría, administración e informática, 5(12), 1-29. https://recai.uaemex.mx/article/view/8927

Borboa-Álvarez, E. P., Valdez-Juárez, L. E., Limón-Ulloa, R., Hernández-Ponce, O. E., \& Saucedo-Monarque, J. (2020). The Role of Responsible Management in Job Satisfaction and Performance Within Banking Firms. Journal of Business, Universidad Del Pacífico (Lima, Peru), 12(1), 82-102. https://doi.org/https://doi.org/10.21678/jb.2020.1429 
Caseiro, N. \& Coelho, A. (2019). The influence of Business Intelligence capacity, network learning and innovativeness on startups performance. Journal of Innovation \& Knowledge, 4(3), 139-145. Doi: 10.1016/j.jik.2018.03.009.

Chebbi, H., Yahiaoui, D., Sellami, M., Papasolomou, I., \& Melanthiou, Y. (2019). Focusing on internal stakeholders to enable the implementation of organizational change towards corporate entrepreneurship: A case study from France. Journal of Business Research, pp. 1-9. Doi: 10.1016/j.jbusres.2019.06.003.

Covin, J.P. y Slevin, D.P. (1991). A conceptual model of entrepreneurship as firm behavior, Entrepreneurship Theory and Practice, 16 (1), 7-25.

Escobar-Pérez, J., \& Cuervo-Martínez, Á. (2008). Validez de contenido y juicio de expertos: una aproximación a su utilización. Avances en medición, 6(1), 27-36.

Davidsson, P. (2015). Entrepreneurial opportunities and the entrepreneurship nexus: A reconceptualization. Journal of Business Venturing, 30(5), pp. 674-695. http://doi.org/10.1016/j.jbusvent.2015.01.002

Denning, S. (2017). The age of Agile. Strategy \& Leadership, 45 (1). pp. 3-10. Doi: 10.1108/SL12-2016- 0086.

Donkor, J., Agyekum, G., Kankam-Kwarteng, C., \& Aidoo, E. (2018). Innovative capability, strategic goals and financial performance of SMEs in Ghana. Asia Pacific Journal of Innovation and Entrepreneurship, 12 (2), pp. 238-254, Doi: 10.1108/APJIE-10-2017-0.

Farrukh, M., Ying, C. W., y Mansori, S. (2016). Intrapreneurial behavior: An empirical investigation of personality traits. Management and Marketing, 11(4), 597-609. https://doi. org/10.1515/mmcks-2016-0018.

Felgueira, T., y Rodrigues, R. G. (2020). I-ENTRE-U: an individual entrepreneurial orientation scale for teachers and researchers in higher education institutions. International Review on Public and Nonprofit Marketing, 17(1), 1-21. https://doi.org/10.1007/s12208-01900226-2

García, J. C., Sánchez, B., Flórez, J., Helena, S., y Gabriel, V. (2017). Entrepreneurial potential, realism and optimism as predictor variables of entrepreneurial intention: Differences between Spain and Portugal.

Gallardo-Vázquez, D., Sánchez-Hernández, M. I., \& Corchuelo-Martinez-Azua, M. B. (2013). Validación de un instrumento de medida para la relación entre la orientación a la responsabilidad social corporativa y otras variables estratégicas de la empresa. Revista de contabilidad, 16(1), 11-23.

Galván-Vela, E., y Sánchez-Limón, M. (2017). Autonomía y recompensas como factores organizacionales detonantes de la actividad intraemprendedora Autonomy and rewards as organizational factors triggering intrapreneurship. Ciencias Administrativas. Teoría y Praxis, 2(13), 237-249.

Guth, W. D. \& Ginsberg, A. (1990). Guest Editors' Introduction: Corporate Entrepreneurship. Strategic Management Journal, 11, 5-15. https://www.jstor.org/stable/2486666.

Ghozali I. y Latan H. 2015. Conceptos, técnicas y aplicaciones de mínimos cuadrados parciales utilizando Programa SmartPLS 3.0. Ed. 2do. Agencia Editorial de la Universidad Diponegoro, Semarang

Göcke, L., Hülsebusch, K. \& Menter, M. (2021) The legitimacy of corporate entrepreneurship: a structured literature review. Manag Rev Q. https://doi.org/10.1007/s11301-021-00246-5

Hornsby, J.S., Kuratko, D.F. y Zahra, S.A. (2002). Middle managers' perception of the internal environment for corporate entrepreneurship: assessing a measurement scale, Journal of Business Venturing, 17 (3), 253-274. 
Jong, J. (2012). The decision to exploit opportunities for innovation: a study of high-tech smallbusiness owners. Entrepreneurship Theory and Practice, 37(2). pp. 281-301. Doi: 10.1111/j.1540- 6520.2011.00459.x

Kearney, C., Hisrich, R. D. y Antoncic, B. (2013). The mediating role of corporate entrepreneurship for external environment effects on performance. Journal of Business Economics and Management, 14(sup1), S328-S357.

Kraus, S., Breier, M., Jones, P. y Hughes M (2019). Individual entrepreneurial orientation and intrapreneurship in the public sector. Int Entrep Manag J 15, 1247-1268. https://doi.org/10.1007/s11365-019-00593-6

Kreiser, P.M., Kuratko, D.F., Covin, J.G. et al. (2021). Corporate entrepreneurship strategy: extending our knowledge boundaries through configuration theory. Small Bus Econ 56, 739-758. https://doi.org/10.1007/s11187-019-00198-x

Kuratko, D. F., Hornsby, J. S. y Covin, J. G. (2014). Diagnosing a firm's internal environment for corporate entrepreneurship. Business Horizons, 57 (1), 37-47. Doi: 10.1016/j.bushor.2013.08.009

Kuratko, D. F., Montagno, G. y Hornsby, J. S. (1990). Developing an intrapreneurial assessment instrument for effective corporate entrepreneurial environment. Strategic Management Journal, 2 (Summer), 49-58. https://www.jstor.org/stable/2486669

Martín-Rojas, R., García-Morales, V., Garrido-Moreno, A., \& García-Sánchez, E. (2020). Can Business Intelligence Enhance Organizational Performance through Corporate Entrepreneurship? En J. Leitão, \& L. Cagica, In Handbook of Research on Approaches to Alternative Entrepreneurship Opportunities (págs. pp. 1-25). IGI Global. Doi: 10.4018/978-1-7998-1981-3.ch010

Morris, M.; Kuratko, D.; Covin, J. (2011). Corporate Entrepreneurship and Innovation: Entrepreneurial Development Within. Mason, OH. USA: South- Western Cengage Learning.

Ospina, R. P., Acosta-prado, J. C., y Castrillón, M. A. G. (2016). Intraemprendimiento y emprendimiento corporativo. Estrategias de renovación empresarial en Colombia. Revista espacios. 37 (34).

Pérez Morfi, D., Núñez Paula, I. A., \& Font Graupera, E. (2019). Metodología de Gestión del Conocimiento para el emprendimiento territorial. Aplicación en el sector ganadero del municipio Yaguajay, Provincia de Sancti Spíritus, Cuba. GECONTEC: Revista Internacional De Gestión Del Conocimiento Y La Tecnología, 7(1), 22-41. Recuperado a partir de https://www.upo.es/revistas/index.php/gecontec/article/view/4054.

Pinchot, G (1985). Intrapreneurship. New York: Harper \& Row

Tobón, S. (2020). Fases para la validación de un instrumento de investigación [taller]. Diseño y validación de instrumentos de investigación.

Tonial, G., \& Ricardo Rossetto, C. (2017). International Entrepreneurial Orientation: the Case of Wineries Participating in the Wines of Brazil Project. Journal of Business, Universidad Del Pacífico (Lima, $\quad$ Peru), $\quad 9(1), \quad$ 23-42. https://doi.org/https://doi.org/10.21678/jb.2017.821

Turró, A., Urbano, D., \& Peris-Ortiz, M. (2014). Culture and innovation: The moderating effect of cultural values on corporate entrepreneurship. Technological Forecasting and Social Change., 88, pp. 360-369. Doi: 10.1016/j.techfore.2013.10.004.

Trujillo, M. A. y Guzmán, A. (2008). Intraemprendimiento: Una revisión al constructo teórico, sus implicaciones y agenda de investigación futura. Cuadernos de Administración, 21 (35), pp. 37-63. 
Urban, B., \& Wood, E. (2017). The innovating firm as corporate entrepreneurship. European Journal of Innovation Management, 20(1), pp. 534-556. Doi: 10.1108/EJIM-10-20160100 .

Zahra, S. (1991). Predictors and financial outcomes of corporate entrepreneurship: An exploratory study. Journal of Business Venturing, 6(4), pp. 259-285. Doi: 10.1016/08839026(91)90019-A. 